CZASOPISMO INŻYNIERII LA¿OWEJ, ŚRODOWISKA I ARCHITEKTURY JOURNAL OF CIVIL ENGINEERING, ENVIRONMENT AND ARCHITECTURE

JCEEA, t. XXXIV, z. 64 (3/I/17), lipiec-wrzesień 2017, s. 487-497, DOI: 10.7862/rb.2017.140

\author{
Patrycja CYNIAK ${ }^{1}$ \\ Iwona SZER ${ }^{2}$ \\ Jacek SZER ${ }^{3}$ \\ Tomasz LIPECKI ${ }^{4}$ \\ Ewa BLAZIK-BOROWA ${ }^{5}$
}

\title{
WPŁYW OBCIĄŻENIA DYNAMICZNEGO NA WYTĘŻENIE KONSTRUKCJI RUSZTOWANIA
}

\begin{abstract}
Rusztowanie budowlane to konstrukcja o specyficznym charakterze, która jest szczególnie podatna na drgania o niskich częstościach. W niniejszej pracy, aby jak najlepiej odwzorować stan rzeczywisty, wykorzystano model numeryczny konstrukcji, w którym uwzględniono rzeczywiste imperfekcje geometryczne, uzyskane na podstawie pomiarów geodezyjnych istniejącego rusztowania, oraz wstawiono warunki brzegowe (podpory), zweryfikowane na podstawie zmierzonych drgań swobodnych konstrukcji. Korzystając ze zweryfikowanego modelu zasymulowane zostało przejście człowieka po rusztowaniu na każdym poziomie roboczym jako zmienne w czasie obciążenie dynamiczne. Przeanalizowano wpływ tego obciążenia na wytężenie konstrukcji rusztowania porównując wartości naprężeń normalnych, które pojawiają się w elementach głównych rusztowania do naprężeń normalnych pochodzących od obciążeń statycznych konstrukcji przyjętych według zaleceń normowych. Analizowane obciążenie przejściem człowieka po rusztowaniu powoduje znaczące wartości naprężeń, dlatego takie obciążenia dynamiczne powinny być szczególnie uwzględniane podczas projektowania konstrukcji rusztowania.
\end{abstract}

Słowa kluczowe: rusztowanie, przejście pracownika, analiza dynamiczna, badania in-situ

\footnotetext{
${ }^{1}$ Autor do korespondencji / corresponding author: Patrycja Cyniak, Politechnika Łódzka, Wydział Budownictwa, Architektury i Inżynierii Środowiska, al. Politechniki 6, 90-924 Łódź; tel. 531029218; patrycja.cyniak@dokt.p.lodz.pl

${ }^{2}$ Iwona Szer, Politechnika Łódzka, Wydział Budownictwa, Architektury i Inżynierii Środowiska, al. Politechniki 6, 90-924 Łódź; iwona.szer@p.lodz.pl

${ }^{3}$ Jacek Szer, Politechnika Łódzka, Wydział Budownictwa, Architektury i Inżynierii Środowiska, al. Politechniki 6, 90-924 Łódź; jacek.szer@p.lodz.pl

${ }^{4}$ Tomasz Lipecki, Politechnika Lubelska, Wydział Budownictwa i Architektury, ul. Nadbystrzycka 40, 20-618 Lublin; lipecki@ pollub.pl

${ }^{5}$ Ewa Błazik-Borowa, Politechnika Lubelska, Wydział Budownictwa i Architektury, ul. Nadbystrzycka 40, 20-618 Lublin; e.blazik@ pollub.pl
} 


\section{Wstęp}

Jednym z problemów związanych z użytkowaniem rusztowań budowlanych jest ich podatność na drgania o niskich częstościach. Głównym czynnikiem wprowadzającym konstrukcję $\mathrm{w}$ drgania jest przejście pracownika po rusztowaniu. Wpływa to negatywnie na konstrukcję poprzez naruszenie kotwienia oraz zwiększenie wytężenia konstrukcji. Celem pracy jest porównanie naprężeń spowodowanych obciążeniem dynamicznym, które jest efektem poruszania się pracownika po rusztowaniu w stosunku do obciążeń normowych. W pracy zostaną zaprezentowane informacje o modelu numerycznym rusztowania, procedura doboru warunków brzegowych (podpór) oraz weryfikacji modelu rusztowania na podstawie pomiarów przyspieszeń drgań, wykonanych na konstrukcji rzeczywistej. Korzystając ze zweryfikowanego modelu zostanie zasymulowane przejście człowieka po rusztowaniu a następnie w pracy przeanalizowany zostanie wpływ tego obciążenia dynamicznego na wytężenie konstrukcji rusztowania.

\section{Opis modelu}

\subsection{Informacja o konstrukcji rzeczywistej}

Rozważane rusztowanie, pokazane na rys. 1., to systemowe rusztowanie ramowe Plettac SL 70 ze stali ocynkowanej ogniowo o szerokości $74 \mathrm{~cm}$. Długość modułu wynosi 3,0 m, natomiast wysokość ramki jest równa 2,0 m. Całkowita długość rusztowania to $21,0 \mathrm{~m}$, a wysokość $9.0 \mathrm{~m}$. Pomosty robocze stanowią dwa podesty drewniane, z wyjątkiem konsol, gdzie zastosowano pomosty aluminiowe. Do głównych elementów rusztowania należą: stojaki, górne i dolne poprzeczki ramki, pomosty robocze, stężenia oraz kotwy. Pozostałe elementy to: poręcze, krawężniki drewniane, trzpienie, łączniki kotwiące, poręcze, podstawki.
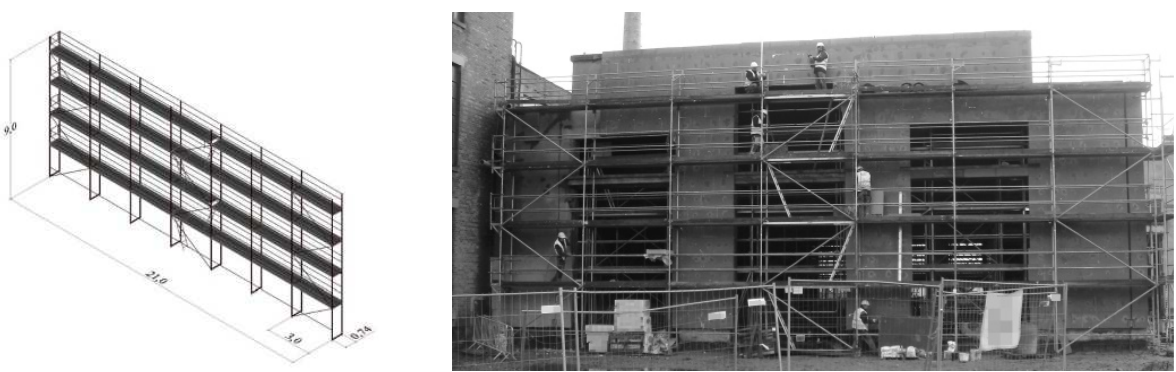

a)

b)

Rys. 1. Rusztowanie budowlane: a) schemat $\mathrm{z}$ wymiarami, b) widok rusztowania

Fig. 1. The scaffolds: a) scheme with dimensions, b) view of the scaffolds 


\subsection{Informacje o wstępnym modelu rusztowania}

Model numeryczny rusztowania opracowano w programie Autodesk Simulation Mechanical (rys. 2.). Wyjściowymi modelami, od których rozpoczęto rozważania był model o idealnej geometrii oraz model o geometrii uwzględniającej imperfekcje, występujące w rzeczywistej konstrukcji. Rzeczywistą geometrię modelu otrzymano na podstawie pomiarów geodezyjnych istniejącego rusztowania.

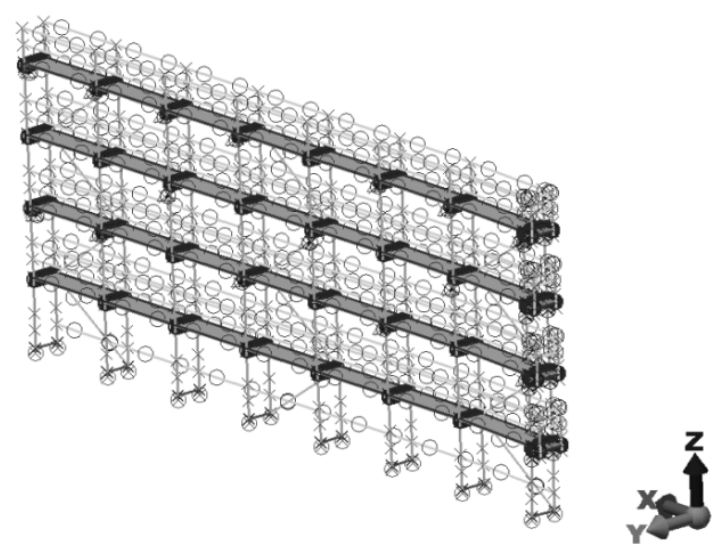

Rys. 2. Model MES Rusztowania

Fig. 2. Scaffold FEM Model

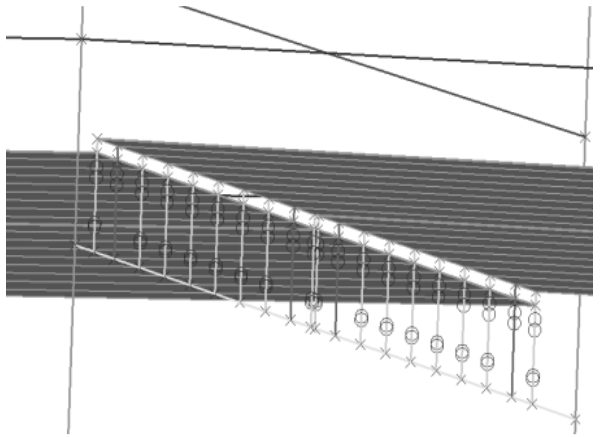

a)

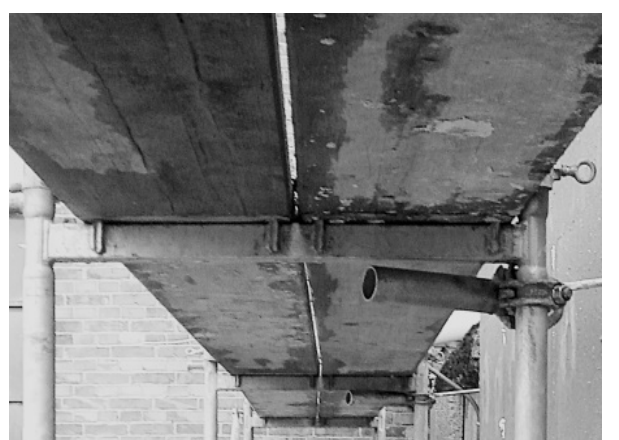

b)

Rys. 3. Połączenie pomostu z ramą: a) model komputerowy połączenia, b) fragment rusztowania

Fig. 3. The connection of a deck and a frame: a) the computer model of a connection, b) the part of scaffolds

Konstrukcję rusztowania odwzorowano jako układ elementów prętowych. Pomosty robocze jako elementy powierzchniowe oparto przegubowo na trzpieniach sztywno połączonych z górną poprzeczką ramki rusztowania. Występujące 
W rzeczywistości trzpienie odwzorowano jako elementy prętowe $\mathrm{z}$ przegubem z jednej strony, natomiast oparcie pomostu na poprzeczce modelują elementy kratowe. Model oraz rzeczywiste połączenie między pomostem a poprzeczką rusztowania zostały przedstawione na rys. 3. Stężenia rusztowania, poręcze i krawężniki wprowadzono jako pręty przegubowo połączone $\mathrm{z}$ rusztowaniem. Podparcie konstrukcji na podłożu odwzorowano za pomocą podpór przegubowych. Zakotwienie rusztowania $\mathrm{w}$ fasadzie budynku za pomocą stalowych kotew przedstawiono jako pręty z pełnym zamocowaniem na jednym końcu. Kotwienie wstępnie zamodelowano za pomocą podpór blokujących wszystkie stopnie swobody, tzn. zablokowano trzy przesuwy i trzy obroty.

Gęstości materiałów zostały dobrane tak, aby masy poszczególnych elementów w modelu były zgodne z masami elementów rzeczywistych, w skład których wchodzą nieuwzględnione w geometrii modelu dodatkowe blachy i trzpienie.

\section{Identyfikacja parametrów dynamicznych}

Na rusztowaniu na budowie przeprowadzono szereg pomiarów przyspieszeń drgań, na podstawie których można zidentyfikować drgania swobodne konstrukcji oraz oszacować tłumienie. W celu wyznaczenia wspomnianych parametrów zastosowano wzbudzenie drgań w trzech punktach (dwa skrajne - A i C, oraz środkowy B) na trzecim poziomie roboczym. Do badań wykorzystano sprzęt Brüel \& Kjær: rejestrator Pulse 3053-B-12 podłączony do przenośnego komputera oraz zestaw trzech akcelerometrów. Punkty pomiarowe znajdowały się poniżej ostatniego poziomu pomostów. Dwa akcelerometry trójosiowe 4506B 003 zostały umieszczone na skrajnych słupkach ram rusztowania, natomiast dwa czujniki jednoosiowe $4508 \mathrm{w}$ środku rusztowania (rys. 4). Przyspieszenia drgań mierzone były przez czujniki trójosiowe w dwóch kierunkach poziomych: $x$ - wzdłuż rusztowania, $y$ - w kierunku poprzecznym oraz w kierunku pionowym $-z$, natomiast czujniki jednoosiowe rejestrowały przyspieszenia w kierunkach poziomych $x$ i $y$.

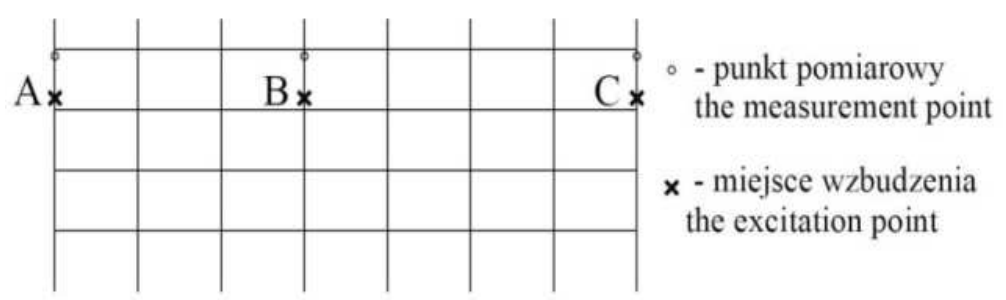

Rys. 4. Schemat umiejscowienia czujników i miejsc wzbudzeń

Fig. 4. The scheme of the sensors and excitation points locations 
Następnie na podstawie 30 przebiegów wykonano analizy FFT (por. [1]), których wynikiem są wykresy pozwalające na wyznaczenie częstości drgań własnych. Przykładowy wykres FFT przyspieszeń pokazano na rys. 7. Na podstawie wyników oszacowano średnie wartości częstotliwości drgań swobodnych konstrukcji. Częstotliwość pierwszej formy drgań swobodnych, wyznaczona na podstawie badań, wynosi $2,5 \mathrm{~Hz}$ (rys. 5). Stwierdzono, że tę formę charakteryzuje drganie całego rusztowania wzdłuż płaszczyzny rusztowania. Kolejna częstotliwość drgań swobodnych ujawniona w badaniach wynosiła $5,5 \mathrm{~Hz}$ a jej forma charakteryzowała się drganiami, w których dominowały przesunięcia w kierunku prostopadłym do rusztowania.

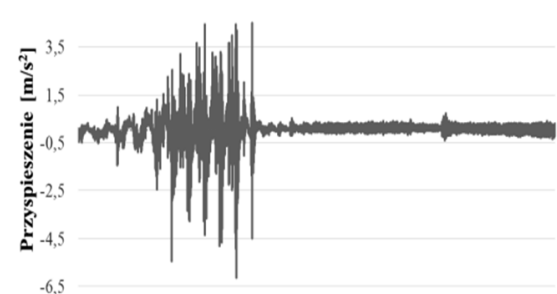

a)

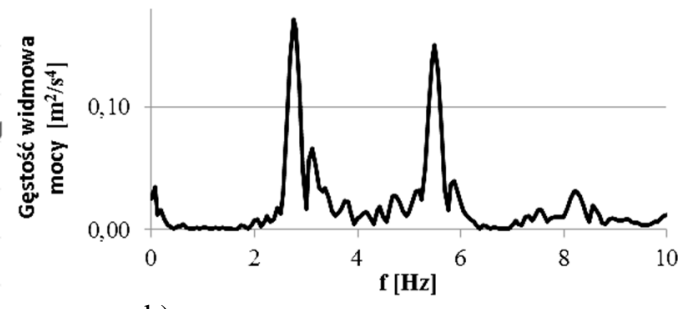

b)

Rys. 5. Przykładowe wyniki pomiarów przyspieszeń: a) wykres przyspieszeń, b) FFT z przyspieszeń

Fig. 5. The exemplary results of acceleration measurement: a) graph of accelerations, b) FFT for accelerations

Wartość współczynnika tłumienia $\gamma^{\prime}$ wyznaczono jako średnią wartość ze współczynników tłumienia oszacowanych w odniesieniu do 4 przebiegów czasowych otrzymanych z badań. Dla każdego z przebiegów określono maksima na wybranym fragmencie wykresu przyspieszeń a następnie aproksymowano je funkcją o wzorze:

$$
y=A_{0} e^{-\gamma t}
$$

Na tej podstawie otrzymano współczynnik tłumienia o wartości $\gamma=7,05 \mathrm{rad} / \mathrm{s}$.

Wyznaczone parametry dynamiczne rusztowania zostały wykorzystane do opracowania ostatecznego modelu rusztowania.

\section{Model numeryczny rusztowania}

\subsection{Dobór warunków brzegowych}

Punktem wyjścia do rozważań na temat prawidłowego odwzorowania konstrukcji było wyznaczenie częstości drgań własnych modelu o geometrii idealnej i modelu z imperfekcjami geometrycznymi. Ponieważ podczas pomiarów wymuszenie było realizowane przez osobę o masie $100 \mathrm{~kg}$, to oprócz częstości drgań własnych rusztowania bez dodatkowych mas wykonano również obliczenia z masą 
$100 \mathrm{~kg}$ umieszczoną odpowiednio w punkcie A, B i C. Obliczenia bez masy są oznaczone jako „,0” a pozostałe literami punktów, w których wstawiano masy.

W wynikach obliczeń drgań własnych obydwu modeli nie ujawniła się oczekiwana wartość pierwszej częstotliwości drgań własnych zbliżonej do 2,5 Hz. Uwzględnienie rzeczywistych imperfekcji zmniejszyło wartość drgań własnych, ale nadal pierwsza częstotliwość drgań własnych była za duża tzn. 4,6 Hz. W kolejnym kroku w obydwu modelach pozostawiono pełne zamocowanie $\mathrm{w}$ fasadzie budynku oraz uwolniono przesuw w kierunku $x$ wzdłuż rusztowania w podporach, do których dochodziły stężenia. Ponieważ wyniki z tego modelu także nie były satysfakcjonujące, to rozważono kolejny wariant modelu, uwzględniający wysoce prawdopodobne niepełne zamocowanie kotew w elewacji, tzn. blokujące tylko przesunięcia Zdecydowano się na badanie zwolnienia obrotów w podporach od górnych poziomów kotwienia, ponieważ czym kotwy znajdują się wyżej tym przesunięcia rusztowania na ich wysokości są większe a zruszenie kotwienia bardziej prawdopodobne. Wykonano szereg obliczeń częstości drgań własnych, w których sprawdzono wpływ na ich wartości kolejno: zwolnienia obrotów w co drugiej podporze na najwyższym poziomie, zwolnienie obrotów wszystkich podpór najwyższego poziomu, zwolnienia obrotów w co drugiej podporze na poziomu niżej, zwolnienie obrotów wszystkich podpór tego poziomu, itd. Ostatecznie zwolniono obroty w podporach, modelujących kotwienie zarówno na wysokości czwartego i trzeciego poziomu roboczego oraz w co drugiej podporze na wysokości drugiego poziomu roboczego. Pierwsza częstotliwość drgań własnych w tym wariancie wyniosła $2,4 \mathrm{~Hz}$, co jest zadowalająco bliskie wartości wynikającej z pomiarów 2,5 Hz (rys. 6). Dodatkowo druga częstotliwość drgań własnych

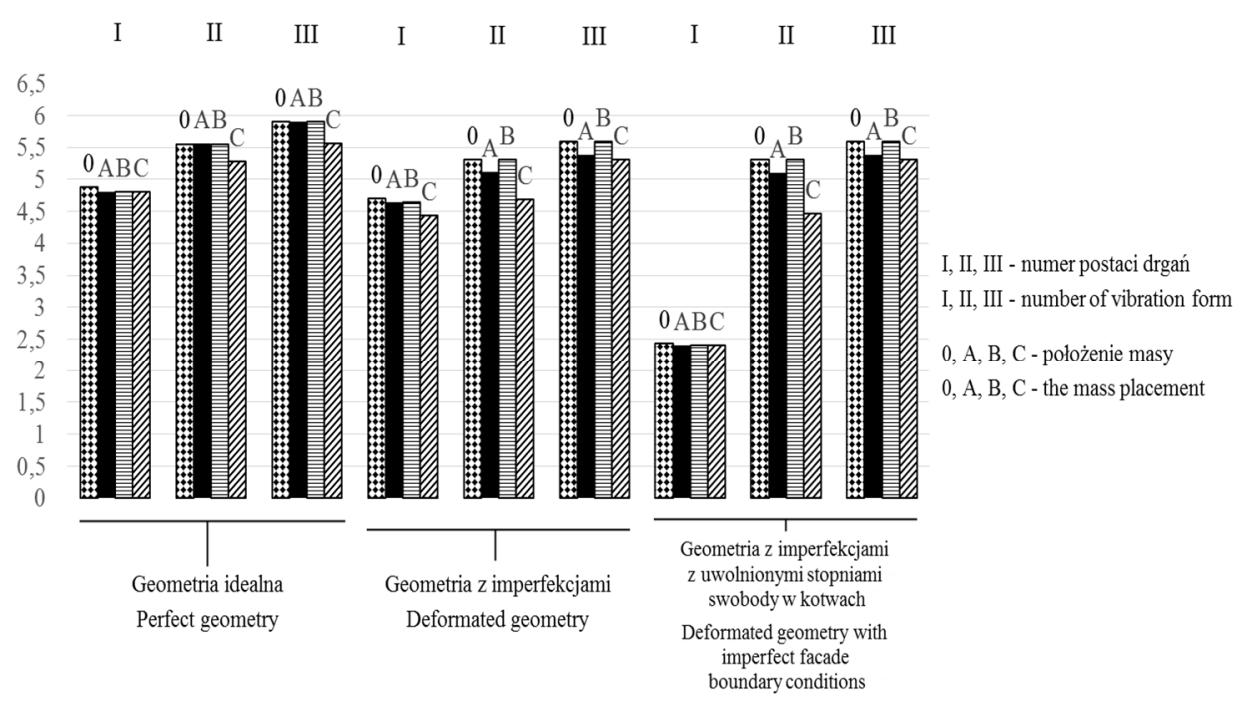

Rys. 6. Porównanie wartości częstości drgań własnych

Fig. 6. The comparison of natural vibrations frequencies 
z obliczeń równa 5,4 Hz jest bardzo bliska wartości drugiej formy drgań swobodnych otrzymanej z badań 5,5 Hz. Również obliczone formy drgań własnych wykazały przesunięcia zgodne z wynikami pomiarów. Dlatego uznano, że model ten prawidłowo odzwierciedla rzeczywistą pracę konstrukcji.

\subsection{Oddziaływanie dynamiczne spowodowane przejściem człowieka}

Przejście człowieka po rusztowaniu rozważane jest jako ruch w kierunku wzdłużnym rusztowania. Miejsca kontaktu stóp z pomostem roboczym znajdują się po obu stronach linii prostej wyznaczonej w środku szerokości pomostu (rys. 7.). Pionowe obciążenie przekazywane przez człowieka na rusztowanie przyjęto równe $1,0 \mathrm{kN}$ (co odpowiada ciężarowi osoby o masie w przybliżeniu równej $100 \mathrm{~kg}$ ). Oprócz składowej pionowej podczas ruchu człowieka należy uwzględnić również składowe poziome obciążenia - w kierunku wzdłużnym rusztowania $x$ oraz poprzecznym $y$. Wartości sił poziomych wyznaczono na podstawie przebiegów okresowych sił wzbudzających w kierunku pionowym, bocznym i wzdłużnym przy założeniu symetrii odziaływania przekazywanego z obu stóp według [2], które wynoszą odpowiednio $20 \%$ i $5 \%$ wartości siły pionowej.

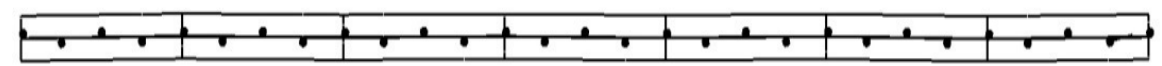

Rys. 7. Miejsca przyłożenia sił na pomostach roboczych podczas ruchu człowieka

Fig. 7. Loads placement during human walk on working platforms

Obciążenie zadano jako zmienne w czasie, ze względu na stopniowe przenoszenie ciężaru z jednej stopy na drugą. W momencie pełnego kontaktu jednej stopy i podniesienie drugiej $100 \%$ obciążenia jest przekazywane poprzez stopę człowieka w miejscu kontaktu jej z pomostem roboczym na rusztowanie. W następnej chwili wartość obciążenia przekazywanego przez tę stopę maleje do zera przy jednoczesnym wzroście wartości obciążenia przekazywanego przez drugą stopę od zera do 100\% (rys. 8.). Dzięki przeprowadzonym próbom ustalo-

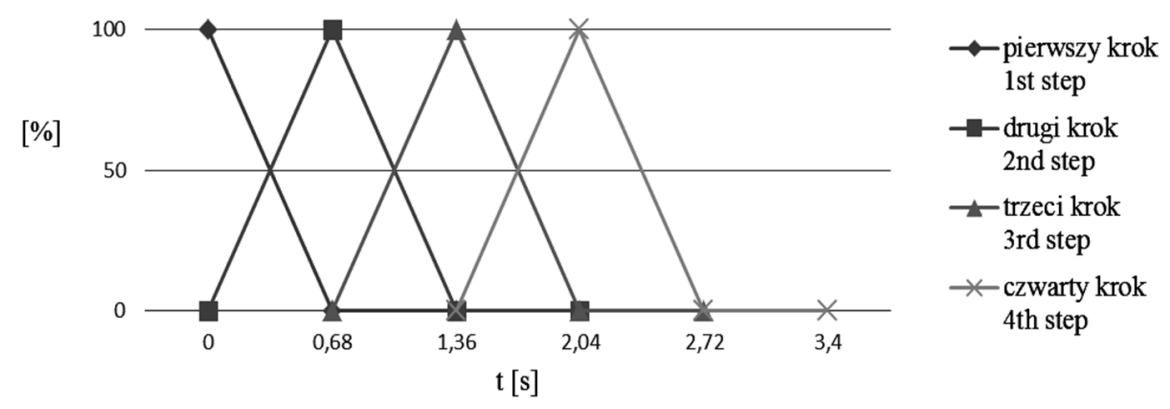

Rys. 8. Procentowy udział przekazywanego obciążenia w kolejnych krokach

Fig. 8. Proportional distribution of loads in next steps 
no czas trwania jednego kroku jako równy $0,68 \mathrm{~s}$ i długość kroku jako równą $0,75 \mathrm{~m}$. Przy takim założeniu przejście przez cały poziom roboczy zajmuje 19,04 s i składa się z 28 kroków.

\subsection{Parametry tłumienia}

Rusztowanie to konstrukcja składająca się $\mathrm{z}$ wielu elementów ze sobą połączonych. Ze względu na znaczną liczbę połączeń między elementami, a także nieperfekcyjny ich montaż, pojawia się dużo luzów, tłumiących drgania. Program Autodesk Simulation Mechanical pozwala na uwzględnienie w obliczeniach dynamicznych współczynnika tłumienia masowego $\alpha$ oraz współczynnika tłumienia sztywnościowego $\beta$ zgodnie z modelem tłumienia Rayleigha. Współczynniki wyznaczono na podstawie pracy [3] i wyniosły $\alpha=1,54(\mathrm{rad} / \mathrm{s})$ oraz $\beta=0,12(\mathrm{~s} / \mathrm{rad})$.

\section{Wyniki analizy}

Korzystając z modelu komputerowego, opisanego w poprzednim punkcie, wykonano analizę zachowania się rusztowania pod wpływem obciążenia zmiennego w czasie. Obciążeniem dynamicznym w niniejszej pracy jest przejście pracownika po poziomie roboczym. Naprężenia normalne powstałe podczas tego przejścia porównano z naprężeniami, które wyznaczono za pomocą analizy statycznej w konstrukcji obciążonej jedynie ciężarem własnym oraz w konstrukcji, do której zgodnie z normą [4] przyłożono na najwyższym poziomie roboczym obciążenie powierzchniowe o wartości $2,0 \mathrm{kN} / \mathrm{m}^{2}$ oraz na jednym poziomie niżej o wartości $1,0 \mathrm{kN} / \mathrm{m}^{2}$.

Rozważono przejście pracownika po każdym z poziomów roboczych. Naprężenia normalne sprawdzono dla głównych elementów konstrukcji, tj. słupków, poprzeczek górnych i dolnych ramy rusztowania oraz kotew. Na rysunku 9. przedstawiono porównanie wartości naprężeń normalnych dla sytuacji obliczeniowej bez uwzględnienia tłumienia oraz z uwzględnieniem tłumienia.

Uwzględnienie tłumienia powoduje zmniejszenie wartości naprężeń w elementach we wszystkich przypadkach. Największe różnice w wartościach naprężeń odnotowano dla przypadku obciążenia przejściem pracownika drugiego poziomu roboczego i wynosiły one w przybliżeniu $6,0 \mathrm{MPa}$ dla kotew, 5,0 MPa dla poprzeczek dolnych, 3,0 MPa dla poprzeczek górnych oraz 2,0 MPa dla słupków ramy rusztowania. 

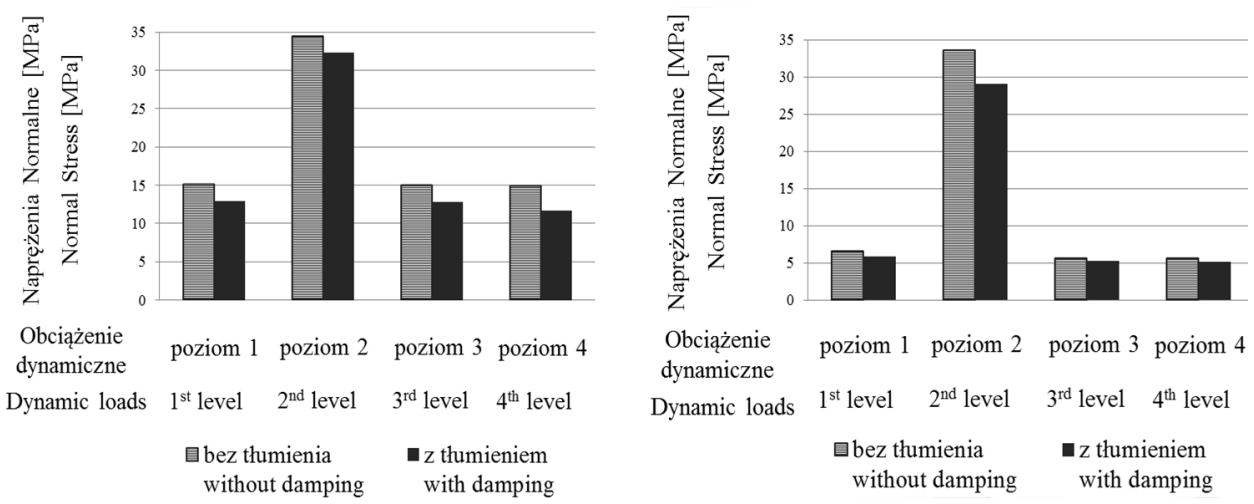

a)

b)
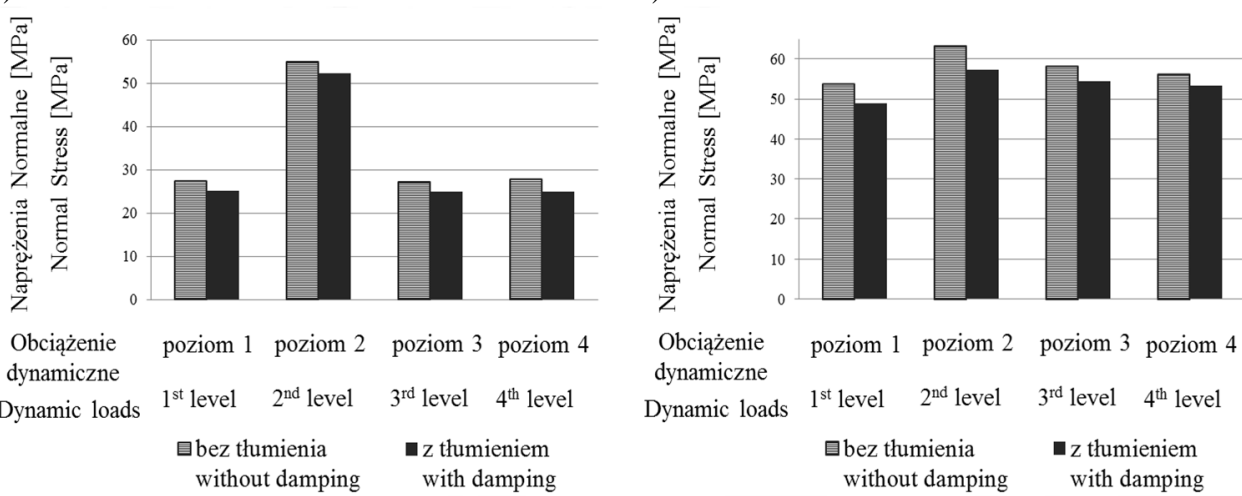

c)

d)

Rys. 9. Maksymalne naprężenia normalne spowodowane przejściem pracownika, w: a) słupkach, b) dolnych poprzeczkach, c) górnych poprzeczkach, d) kotwach

Fig. 9. The maximum normal stress caused by the passage of the employee for: a) standards, b) lower transom, c) upper transom, d) anchors

Najbardziej niekorzystnym okazało się wprowadzenie obciążenia dynamicznego na drugim poziomie roboczym. Największe naprężenia wystąpiły w kotwach i wynosiły $57,4 \mathrm{MPa}$, niewiele mniejsze naprężenia pojawiły się w górnych poprzeczkach ramy rusztowania o wartości 52,2 MPa. Maksymalne naprężenia w słupkach to $32,3 \mathrm{MPa}$ i niewiele od nich mniejsze w dolnych poprzeczkach ramy rusztowania równe $29,0 \mathrm{MPa}$. 


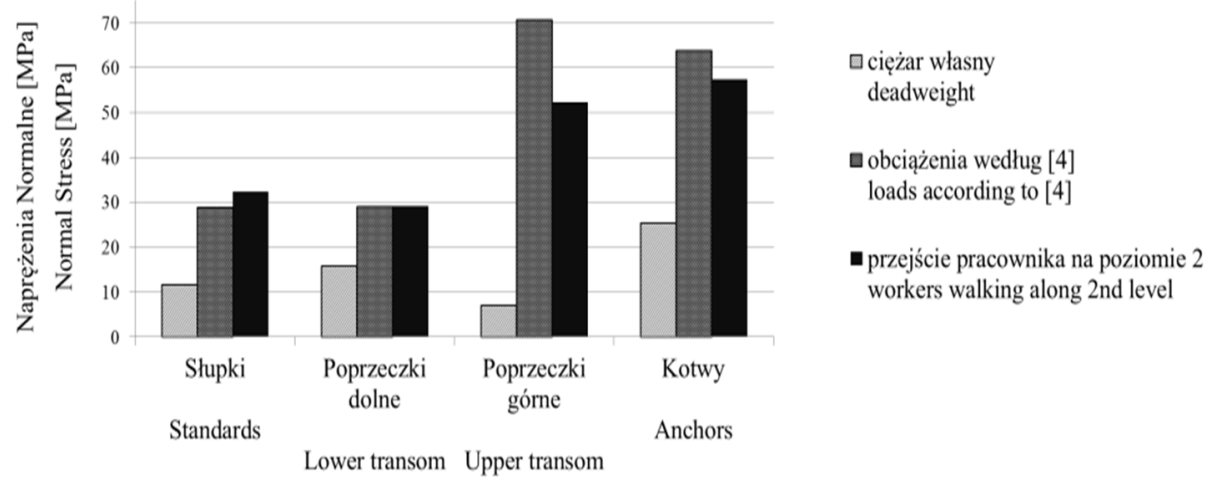

Rys. 10. Porównanie wartości naprężeń normalnych w elementach rusztowania wywołanych statycznymi i dynamicznymi obciążeniami

Fig. 10. The comparison of normal stress in scaffolding elements caused by static and dynamic loads

$\mathrm{Na}$ rysunku 10. pokazano porównanie naprężeń normalnych wywołanych przejściem pracownika i naprężeń od statycznego eksploatacyjnego obciążenia, przyjętego zgodnie z normą [4]. Naprężenia normlane, spowodowane obciążeniem dynamicznym $\mathrm{w}$ postaci przejścia pracownika po podestach drugiego poziomu roboczego, osiągają wartości porównywalne do wartości naprężeń, które uzyskuje się przy obciążeniu normowym. $\mathrm{Z}$ analizy wynika, że rozważane obciążenie dynamiczne powinno być szczególnie uwzględniane podczas projektowania konstrukcji rusztowania ze względu na powodowane znaczące wartości naprężeń w elementach.

\section{Wnioski}

Obciążenia dynamiczne konstrukcji rusztowania w postaci przejścia pracownika po poziomie roboczym powinny być szczególnie uwzględniane podczas projektowania konstrukcji rusztowania, czego obecnie się nie wykonuje z powodu braku tego typu zaleceń w normach [4] i dokumentacjach technicznych rusztowań. Obciążenie to wywołuje w elementach rusztowania naprężenia porównywalne do wartości naprężeń wywoływanych przez obciążenia normowe.

W pracy nie uwzględniono masy człowieka przechodzącego po pomostach roboczych, która może okazać się istotna przy dalszych rozważaniach na ten temat. W przypadku analizy dynamicznej obiektów budowlanych masa człowieka nie jest istotna $\mathrm{w}$ porównaniu $\mathrm{z}$ masą konstrukcji. W przypadku rusztowania człowiek o masie ok. $100 \mathrm{~kg}$ oddziałuje na pomost o masie ok. $45 \mathrm{~kg}$, czyli o ok. połowę mniejszą. Dlatego w przyszłości planowane są badania z uwzględnieniem ruchu masy. Ponadto w pracy przyjęto uproszczony model przejścia pracownika. Sposób przekazywania obciążenia osoby przemieszczającej się jest znacznie bar- 
dziej skomplikowany (por. [2]), co w kolejnych etapach badań zostanie również uwzględnione. W przyszłości planowane są dokładniejsze analizy, które pozwolą na opracowane wniosków przydatnych w praktyce inżynierskiej.

Informacje dodatkowe: Artykut jest wynikiem realizacji projektu badawczego „Model oceny ryzyka wystapienia katastrof budowlanych, wypadków i zdarzeń niebezpiecznych na stanowiskach pracy $z$ wykorzystaniem rusztowań" finansowanego przez NCBiR w ramach PBS3 na podstawie umowy $\mathrm{nr}$ PBS3/A2/19/2015.

\section{Literatura}

[1] Broch J. T.: Mechanical Vibration and Shock Measurements, available from Bruel \& Kjaer Instruments, Inc., Marlborough, MA, Oct. 1980.

[2] Živanović S., Pavic A., Reynolds P.: Vibration Serviceability of Footbridges under Human-induced Excitation: a Literature Review, Journal of Sound and Vibration 279, 2005, s. 1-74.

[3] Wielgos P.: Ocena skuteczności działania wielokrotnych, strojonych tłumików masowych w konstrukcjach budowlanych; Rozprawa doktorska; Politechnika Lubelska Wydział Budownictwa i Architektury, 2010.

[4] PN-EN 12811-1. Tymczasowe konstrukcje stosowane na placu budowy. Część 1: Rusztowania Warunki wykonania i ogólne zasady projektowania; PKN, Warszawa 2007.

\section{IMPACT OF DYNAMIC LOAD ON SCAFFOLD CONSTRUCTION EFFORT}

\section{S u m m a r y}

Scaffolding is very specific type of construction, especially susceptible to low frequency vibrations. Employees walking on the scaffold cause construction vibrations. It has negative influence on construction which is the breach of anchors and increase of construction effort. In this paper numerical model is verified for the best representation of real construction. Imperfections received from geodetic measurements of the real construction were taken into account. Different boundary conditions were considered, because of their impact on construction vibrations. The vibrations were taken as comparative parameter. During natural vibrations analysis excitations in three different points of scaffold were considered. Results of automatic calculations were compared with free vibrations of construction, which was identified basing on measurements of vibration accelerations performed on the scaffold. Employee's walking on every working level as a variable in time dynamic load was simulated on verified numerical model. Impact of this load on construction effort was analysed by comparing normal stress values which appeared in main elements of scaffold (standards, upper transom, lower transom, anchors) to normal stress values caused by static loads according to standard recommendations. Analysed dynamic load induced by walking an employee on scaffold causes significant values of stress in main scaffold elements. These values are almost the same as values of stress derived from static loads according to standard recommendations. In conclusion, dynamic loads as before should be particularly taken into consideration during designing scaffold construction.

Keywords: scaffolds, passage of employee, dynamic analysis, full-scale measurements

Przestano do redakcji: $12.06 .2017 \mathrm{r}$.

Przyjęto do druku: 01.09.2017 r. 